\title{
Paroxysmal Nocturnal Hemoglobinuria Presenting with Hemolysis and Abdominal Pain
}

\section{Hemoliz ve Karın Ağrısıyla Ortaya Çıkan Paroksismal Noktürnal Hemoglobinüri}

\author{
Tahir Darçın, Alparslan Merdin, Nurgül Özcan, Mehmet Bakırtaş, Mehmet Sinan Dal, Dicle \\ İskender, Merih Kızıl Çakar, Fevzi Altuntaş
}

University of Health Sciences Ankara Dr. Abdurrahman Yurtaslan Oncology Training and Research Hospital, Hematology Clinic and Bone Marrow Transplantation Unit

Dergiye Ulaşma Tarihi: 25/01/2019 Dergiye Kabul Tarihi: 26/07/2019 Doi: 10.5505/aot.2019.46034

\section{ÖZET}

GíRISS: PNH da vücudun sık tromboz görülmeyen bölgelerinde tromboz görülebilir. Karın ağrısı, halsizlik, erektil disfonksiyon, baş ağrısı, sırt ağrısı, yutma güçlüğü, damar tıkanıklığı veya hemoliz bulguları görülebilir. OLGU: 26 yaşında erkek hasta halsizlik ve karın ağrısı şikayeti ile hastaneye başvurdu. Hastanın epigastrik bölgede birkaç aydır olan yemeklerden bağımsız ve kendi kendine gelip geçici tarzda aralıklı olan bir karın ağrısı

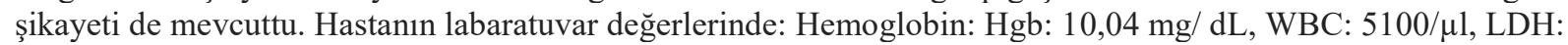
964,8 U/L, indirekt bilirubin: 1,3 mg/ dL retikülosit sayıs1: 179 bin, transferrin saturasyonu: \% 15,6, kreatin: 0,62 mg/dL, sedimantasyon: $38 \mathrm{~mm} / \mathrm{saat}$, CRP: 19,6 INR: 1,22 trombosit: 143 bin, direkt coombs: negatif, indirekt coombs: negatif. Vitamin B12, folik asit ve ferritin düzeyleri ise normal sınırlarda idi. Periferik yaymada lenfoplazmositer hücre artışı mevcuttu, monositlerde artış mevcuttu, fragmente eritrosit izlenmedi, atipik hücre veya blast izlenmedi. Non-immün hemolitik anemisi mevcut olan hastaya PNH testi istenildi. PNH testi sonucu: Flow sitometrik analizde granülositlerde $\% 95$, monositlerde $\% 96$, eritrositlerde $\% 5,9$ ( TIP II+ TIP III ) PNH klonunun varlığını göstermektedir. Flow sitometrideki beyaz kürelerle eritrositlerin klon büyüklükleri arasındaki farkın hemolize ve/veya transfüzyona baglı olabileceği yorumunda bulunulmuş. d-dimer: 1350 olan hastaya clexan $2 \times 0,6$ cc başlanıldı.Hastaya eculizumab tedavisi başlanıldı. Eculizumab tedavisi sonrasında hastanın şikayetleri geriledi, semptomları duzeldi.

TARTIŞMA: Bizim olgumuzda da olduğu gibi karın ağrısı olan bir hastada eşlik eden hemoliz bulgusu varsa mutlaka PNH tanısı da ayırıcı tanıda düşünülmelidir. Hastalara hızlı bir şekilde başlanacak ekullizumab tedavisi ile tromboembolik riskin de azaltılması sağlanıp sağkalım süresinin uzaması sağlanabilecektir.

Anahtar Kelimeler: paroksismal noktürnal hemglobinüri, hemoliz, karın ağrısı

\begin{abstract}
INTRODUCTION: Abdominal pain, fatigue, erectile dysfunction, headache, back pain, dysphagia,renal insufficiency, vascular occlusion or hemolysis might be seen in PNH.

CASE: A 26-year-old male patient presented to the hospital with fatigue and abdominal pain. The patient complained of an abdominal pain that was not related with the meals. He had intermittent abdominal pain in the epigastric region for a few months. Labaratory values were as Hemoglobin: 10,04 mg / dL, WBC: 5100 /, creatinine: $0.62 \mathrm{mg} / \mathrm{dL}$, sedimentation: $38 \mathrm{~mm} / \mathrm{h}$, CRP: 19.6, INR: 1.22, platelets: 143 thousand, direct coombs: negative, indirect coombs: negative, $\mathrm{LDH}$ : 964,8 U / L, indirect bilirubin: 1,3 mg / dL, reticulocyte count: 179 thousand, transferrin saturation: 15,6 \%. Vitamin B12, folic acid and ferritin levels were with in normal limits. Peripheral blood smear showed an increase in lymphoplasmacytic cells, an increase in monocytes, no fragmented erythrocytes and no atypical cells or blasts. PNH test was done by flowcytometry to the patient with non-immun hemolytic anemia. Flowcytometric analysis showed the PNH clone in $95 \%$ of granulocytes, in 96\% of monocytes and in 5.9\% of erythrocytes (Type II + Type III). It has been interpreted that the clonal PNH rate difference between the white cells and erythrocytes in the flow cytometric analysis might be due to hemolysis and/or transfusion. The patient was started to enoxaparine $2 \times 0,6 \mathrm{cc}$ subcutaneously treatment due to the result of D-dimer value which was found as 1350. Eculizumab treatment was started. His symptoms have improved and his complaints have disappeared after eculizumab treatment.
\end{abstract}

DISCUSSION: If a patient with an abdominal pain had hemolysis as in our case, PNH should be kept in mind. Rapid eculizumab treatment would benefit these patients. 
Keywords: paroxymal nocturnal hemoglobinuria, hemolysis, abdominal pain

\section{INTRODUCTION}

PNH (Paroxysmal Nocturnal Hemoglobinuria), previously known as MarchiafavaMichelisyndrome, is an acquired hemolytic anemia caused by deficient glycosyl phophotidylinositol (GPI) anchoring proteins,named as CD55 and CD59.A somatic mutation in the X-linked phosphatidyl inositol glycan class A (PIGA) gene results in deficient anchoring protein GPI. PNH is characterised by increased sensitivity to activated complement that leads to lysis (1). Abdominal pain, fatigue, erectile dysfunction, headache, back pain, dysphagia ,renal insufficiency, vascular occlusion or hemolysis might be seen in PNH. Thrombosis could develop in unusual sites of body as spleen, CNS. There is an increased risk of leukemia .Previously supportive and symptomatic treatment were the only managemet strategy. Recently specific targeted treatment of the disease has saved many patients from lifethreatening complications of PNH .Eculizumab a humanized monoclonal antibodyis a C5 monoclonal inhibitor that blocks the distal complement pathway, so red cells are escaped from complement-mediated lysis.Eculizumab has become a standard treatment of PNH. Eculizumab could also reduce the risk of thromboembolic events. The annual incidence of PNH was reported as $0.13 / 100.000$ (2). This is a case of a young male who presented with fatigue and abdominal pain at the age of 26 years.

\section{CASE}

A 26-year-old male patient presented to the hospital with fatigue and abdominal pain. The patient complained of an abdominal pain that was not related with the meals. He had intermittent abdominal pain in the epigastric region for a few months. The patient did not have a known concomittant chronic disease. He works as a barber.Labaratory values were as Hemoglobin: 10,04 mg / dL, WBC: $5100 /$, creatinine: $0.62 \mathrm{mg} / \mathrm{dL}$, sedimentation: 38 mm / h, CRP: 19.6, INR: 1.22 , platelets: 143 thousand, direct coombs: negative, indirect coombs: negative, LDH: 964,8 U / L, indirect bilirubin: $1,3 \mathrm{mg} / \mathrm{dL}$, reticulocyte count: 179 thousand, transferrin saturation:15,6\%. Vitamin B12, folic acid and ferritin levels were with in normal limits. Peripheral blood smear showed an increase in lymphoplasmacytic cells, an increase in monocytes, no fragmented erythrocytes and no atypical cells or blasts. PNH test was done by flowcytometry to the patient with non-immun hemolytic anemia. Flowcytometric analysis showed the $\mathrm{PNH}$ clone in $95 \%$ of granulocytes, in $96 \%$ of monocytes and in $5.9 \%$ of erythrocytes (Type II + Type III)( figure 1). It has been interpreted that the clonal $\mathrm{PNH}$ rate difference between the white cells and erythrocytes in the flow cytometric analysis might be due to hemolysis and/or transfusion. The patient was started to enoxaparine $2 \mathrm{x} 0,6 \mathrm{cc}$ subcutaneously treatment due to the result of $\mathrm{D}$-dimer value which was found as 1350. Portal doppler ultrasonography showed no thrombosis. And lower extremity doppler ultrasonography did not show any deep vein thrombosis. Splenomegaly was revealed in portal venous ultrasonography. The spleen was $163 \mathrm{~mm}$, the liver was $169 \mathrm{~mm}$ and portal vein diameter was $13 \mathrm{~mm}$. Ultrasonography also revealed a $5.5 \mathrm{~cm}$ isoechoicarea in the lower pole of the spleen. Upperendoscopy showed polyps and antral gastritis. Pulmonary tomography angiography showed no embolism. Eculizumab treatment was started to the patient.

\section{DISCUSSION}

Paroxysmal nocturnal haemoglobinuria (PNH), a rare disease with an annual incidence of 0.13 / 100.000 , is a life-threatening disorder,that might be characterized by hemolysis, abdominal pain, fatigue, erectile dysfunction, headache, backpain, dysphagia ,renal insufficiency and thrombosis in unusal vessels (2). PNH is an intravascular hemolyticdisorder. A clonal disorder of hematopoietic stem cells related to a somatic mutation in the PIGA gene This mutation leads to hemolysis, thrombosis and cytopenias.In addition,similar clinical features could also be seen in parasitary infections, microangiopathic 
hemolytic anemias, inherited metabolic disorders and enzymatic deficiencies (3-5). Consequently, differential diagnosis should be done carefully.

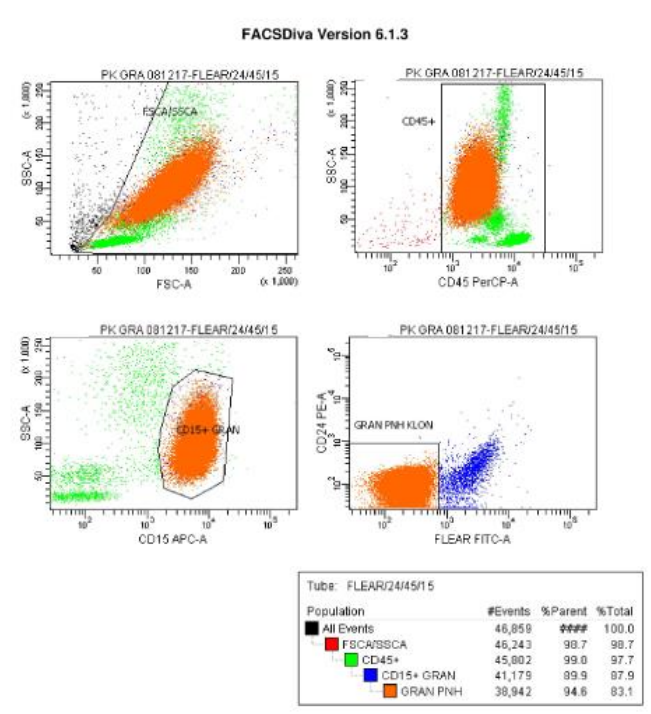

Figure 1. Flow cytometric analysis of the granulocyte

The 10-year thrombosis risk for a granulocyte PNHclone over $>50 \%$ was reported as $44 \%$, whereas the 10-year thrombosis risk for a granulocyte PNH clone $<50 \%$ was reported as $5.8 \%$ (6). Despite the high risk of thrombosis, there has been no clear guideline on the necessity of anticoagulation prophylaxis. Thrombosis was reported as a leading cause of mortality in PNH (7). Eculizumab is a C5 monoclonal inhibitor and it has become a standard treatment of PNH. Eculizumab could also reduce the risk of thromboembolic events (8). Patients treated with eculizumab has a survival of 10 to 22 years (9). If a patient with an abdominal pain had hemolysis as in our case, PNH should be kept in mind. Rapid eculizumab treatment would benefit these patients.

\section{ACKNOWLEDGEMENTS}

Patient's written consent was taken for this publication. The abstract was presented in the 1. Hematolojik Nadir Hastalıklar Kongresi,inFebruary 2018, in K.K.T.C.

\section{REFERENCES}

1. How we treat paroxysmal nocturnal hemoglobinuria: A consensus statement of the Canadian PNH Network and review of the national registry .Eur $\mathrm{J}$ Haematol. 2018;1-17.

2. Hill, A., Platts, P. J., Smith, A., Richards, S. J., Cullen, M. J., Hill, Q. A., Roman, E., \& Hillmen, P. (2006). The Incidence and Prevalence of Paroxysmal Nocturnal Hemoglobinuria (PNH) and Survival of Patients

in Yorkshire.. Blood, 108(11), 985.

3. Merdin A, Avci Merdin F, Karaca M, Güzelay N. Pansitopenisi Olan Erişkin Mukopolisakkaridoz Tip 3B Olgusu: Nadir Bir Olgu Sunumu. Med Bull Haseki 2014; 52: 232-234.

4. Merdin A. Parasitic Diseases as Differential Diagnosis in the Field of Hematology.Turkiye Parazitol Derg. 2017 Mar;41(1):60-61.

5. Merdin A, Avci F, Güzelay N. Glucose-6phosphate dehydrogenase deficiency presented with convulsion: a rare case.Hematol Rep. $2014 \quad$ Mar 26;6(1):5266.

6. Hall, C., Richards, S., \& Hillmen, P. (2003). Primary prophylaxis with warfarin prevents thrombosis in paroxysmal nocturnal hemoglobinuria (PNH). Blood,102(10), 3587-

3591. Accessed January 10, 2018.

7. Socié G, Mary JY, de Gramont A, et al. . Paroxysmal nocturnal haemoglobinuria: long term follow up and prognostic factors: French Society of Haematology. Lancet 1996;348:573-577

8. 8. Hillmen, P., Muus, P., Dührsen, U., Risitano, A. M., Schubert, J., Luzzatto, L., Schrezenmeier, H., Szer, J., Brodsky, R. A., Hill, A., Socié, G., Bessler, M., Rollins, S. A., Bell, L., Rother, R. P., \& Young, N. S. (2007). Effect of the complement inhibitor eculizumab on thromboembolism in patients with paroxysmal nocturnal hemoglobinuria. Blood, 110(12), 4123-4128.

9. MGriffin and TMunir. Management of thrombosis in paroxysmal nocturnal hemoglobinuria: a clinician'sguide.Ther Adv Hematol. 2017 Mar; 8(3): 119-126. 